процессуальному представительству должны быть унифицированы и закреплены во всех процессуальных кодексах Российской Федерации.

$$
\text { *** }
$$

1. Конституция Российской Федерации (принята всенародным голосова-нием 12.12.1993) (с учетом поправок, внесенных Законами РФ о поправках к Конституции РФ от 30.12.2008 N 6-ФКЗ, от 30.12.2008 N 7-ФК3, от 05.02.2014 N 2-ФКЗ, от 01.07.2020 N 11-ФК3) // Собрание законодательства РФ, 01.07.2020, N 31, ст. 4398.

2. Соловьев А.А. Высшее юридическое образование как обязательное ква-лификационное требование к судебным представителям. - М., 2015. № 3. - С. 137-144.

3. Гринь Е.А. Процедура медиации в спорах, связанных с интеллектуаль-ной собственностью: проблемы и перспективы. // Аграрное и земельное право2019. № 8 (176). С. 106-107.

4. $\quad$ Гринь Е.А., Градинар Э.В. О судебном (процессуальном) представитель-стве и представительстве по назначению суда // Аграрное и земельное право. 2020. № 9 (189). С. 129-132.

\title{
Гусейнова Р.А. \\ Управление многоквартирным домом: перспективы развития товариществ собственников жилья
}

Дальневосточный федеральный университет (Россия, Владивосток)

doi: $10.18411 / \mathrm{lj}-06-2021-204$

Научный руководитель

Погодина Т.И.

\section{Аннотация}

В статье дается понятие управления многоквартирным домом, названы формы управления многоквартирным домом, раскрывается понятие товариществ собственников жилья и говорится о перспективах развития товариществ в нашей стране.

Ключевые слова: многоквартирный дом, товарищество собственников жилья, формы управления многоквартирным домом, управляющая компания.

\section{Abstract}

The article gives the concept of management of an apartment building, names the forms of management of an apartment building, reveals the concept of homeowners' associations and talks about the prospects for the development of associations in our country.

Keywords: apartment building, homeowners' association, forms of management of an apartment building, management company.

Под управлением многоквартирным домом (далее МКД) понимают согласованную деятельность собственников помещений в МКД, или лиц, привлеченных ими, которая направлена на обеспечение благоприятных и безопасных условий проживания граждан, надлежащего содержания общего имущества в МКД, решения вопросов пользования общим имуществом, а также предоставления коммунальных услуг гражданам, которые проживают в таком доме.

В юридической литературе понятие «управления МКД» освещено не в достаточной степени, поэтому имеет смысл обратиться к подзаконным правовым актам, которые принимаются в развитие жилищного законодательства. В Правилах осуществления деятельности по управлению МКД дается соответствующее понятие в п. 2: «Под деятельностью по управлению МКД понимается выполнение стандартов, направленных на достижение целей, установленных ст. 161 ЖК РФ, а также 
определенных решением собственников помещений в МКД». Я считаю, что данное определение не отражает всей сущности управления МКД.

Управление МКД должно пониматься как жилищное правоотношение, связанное с активной деятельностью собственников жилых помещений, товариществ собственников жилья (далее ТСЖ) или управляющих организаций по поводу обеспечения благоприятных и безопасных условий проживания граждан, надлежащего содержания общего имущества в МКД, решения вопросов пользования общим имуществом, а также предоставления коммунальных услуг гражданам, которые проживают в таком доме. Именно такая трактовка и понимание «управления МКД» на мой взгляд отражает все признаки данного понятия, а также аккумулирует положения жилищного законодательства. Кроме того, предложенное определение содержит важное указание (которое отсутствует и в законодательной формулировке ч. 1 ст. 161 ЖК РФ, и в доктрине) - формы управления.

Формы управления МКД - это конкретный вариант деятельности по управлению МКД в зависимости от субъекта и особенностей управления.

Принятие ключевых решений, касающихся судьбы МКД, в том числе выбор формы управления относится к ведению общего собрания. Однако выбор ограничен формами, указанными в ст. 161 ЖК РФ:

1) непосредственное управление собственниками помещений в МКД, количество квартир в котором составляет не более чем тридцать;

2) управление товариществом собственников жилья либо жилищным кооперативом или иным специализированным потребительским кооперативом;

3) управление управляющей организацией.

В качестве исключения, в законодательстве действует случай, когда выбор формы управления возможен не общим собранием собственников, а органами местного самоуправления. В случае если собственники помещений в МКД не выбрали или не реализовали форму управления своим домом, то органы местного самоуправления в установленный срок проводят отбор управляющей организации на открытом конкурсе.

Из-за низкой активности собственников помещений в МКД сроки окончания проведения органами местного самоуправления открытых конкурсов по отбору управляющих организаций для управления МКД в случае отсутствия выбора способа управления МКД собственниками помещений не раз переносились с 1 марта 2006 г. на 1 января 2007 г., а потом до 1 мая 2008 г. Законодатель таким образом реагировал на ситуацию, когда собственники помещений в МКД не проводили к установленному сроку общие собрания по выбору способа управления МКД. А муниципалитеты, которые как собственники части помещений в МКД имели возможность инициировать общие собрания или оказывать помощь гражданам-собственникам в их проведении, все же предпочитали общим собраниям проведение конкурсов, насаждая аффилированные управляющие организации.

Такая ситуация, когда собственники жилых помещений, с одной стороны, и муниципальная власть, с другой, конечно же создает конфликтную обстановку между этими субъектами, а равно возможность для коррупционных махинаций со стороны органов местного самоуправления при выборе управляющей организации. На этой же почве, а также исходя из смысла законодательного регулирования необходимо признать объективное существование и конкуренции форм управления МКД. Действительно, в ситуации, когда каждая из форм имеет свою законодательную специфику создается выбор между ними, при котором также необходимо прийти к одному единственному решению. На практике довольно трудно уравнять в регулировании общность собственников жилых помещений, создавших ТСЖ, и такие коммерческие организации, как управляющие компании. Тем не менее законодательная допустимость множественности способов управления МКД, которые выбираются 
непосредственно пользователями этой услуги, является детерминантой, влияющей на процессы демонополизации в данной сфере.

Таким образом, отмечу, что de jure конкуренция форм управления МКД имеет место быть, однако de facto она наблюдается достаточно незаметно - на это указывает неутешительная статистика - на первый план выходят управляющие компании, оставляя ТСЖ далеко в конце.

Выяснив, что из себя представляет управление многоквартирным домом, перейдем непосредственно к понятию «ТСЖ».

В отличие от понятия «управление МКД» жилищное законодательство дает нам понятие «ТСЖ» в ч. 1 ст. 135 ЖК РФ. В статье сказано, что ТСЖ признается вид товарищества собственников недвижимости, представляющий собой объединение собственников помещений в многоквартирном доме для совместного управления общим имуществом в многоквартирном доме либо в случаях, указанных в части 2 статьи 136 настоящего Кодекса, имуществом собственников помещений в нескольких многоквартирных домах или имуществом собственников нескольких жилых домов, обеспечения владения, пользования и в установленных законодательством пределах распоряжения общим имуществом в многоквартирном доме либо совместного использования имущества, находящегося в собственности собственников помещений в нескольких многоквартирных домах, или имущества, принадлежащего собственникам нескольких жилых домов, осуществления деятельности по созданию, содержанию, сохранению и приращению такого имущества, предоставления коммунальных услуг лицам, пользующимся в соответствии с настоящим Кодексом помещениями в данных многоквартирных домах или данными жилыми домами, за исключением случаев, предусмотренных статьей 157.2 настоящего Кодекса, а также для осуществления иной деятельности, направленной на достижение целей управления многоквартирными домами либо на совместное использование имущества, принадлежащего собственникам помещений в нескольких многоквартирных домах, или имущества собственников нескольких жилых домов.

Данное определение является, на мой взгляд, громоздким и не совсем понятным, поэтому проанализировав признаки ТСЖ, можно сказать, что под ТСЖ понимается объединение собственников жилых помещений в МКД, зарегистрированное в установленном порядке в качестве юридического лица, созданное в целях управления МКД и общим имуществом собственников в МКД, а также для создания, содержания, сохранения и приращения указанного имущества.

ТСЖ имеют важное значение для повышения качества жизни, развития городов и модернизации общественных услуг. ТСЖ создают исключительно благоприятные возможности для самоорганизации граждан ввиду наличия прямой и хорошо осознанной ими материальной заинтересованности, юридических предпосылок и государственной поддержки: люди хотят, чтобы дом хорошо сдержался, чтобы в нем было чисто, безопасно и приятно жить. Кроме того, люди являются собственниками квартир, а рыночная цена квартир напрямую зависит от состояния дома. В силу названных причин ТСЖ могут служить «лакмусовой бумажкой» способности российского общества к самоорганизации.

Такая форма управления МКД, как ТСЖ, открывает широкие перспективы, ее члены могут контролировать весь процесс коммунального обслуживания, самостоятельно выбирать структуру или организацию, которая представит наиболее выгодные условия коммунального обслуживания, контролировать расход средств, определять размеры и направления финансовых расходов на жилищно-коммунальные услуги, защищать права и законные интересы граждан, решать другие задачи.

Здесь члены товарищества выступают как коллектив единомышленников, связанных как общим интересом по созданию благоприятных, но не обременительных условий проживания в многоквартирном доме, необходимостью совместной 
эксплуатации общего имущества, так и общностью территории проживания. Такое сплетение интересов с одной стороны делает систему достаточно сложной в плане управления, но с другой стороны, создает условия для воспитания эффективного собственника, хозяина, способного решать свои задачи с учетом коллективных потребностей. Здесь граждане будут приобретать хозяйственный, правовой опыт в решении, как частных, так и коллективных проблем. Подобный опыт будет полезен и в рамках развития местного самоуправления. ТСЖ можно рассматривать как форму территориальной организации граждан, как форму их самоуправления на локальном уровне. Самоорганизация граждан является одной из демократических форм объединения индивидов или их общностей для рационального достижения тех или иных целей с помощью наиболее демократических методов по решению того же коллектива (сообщества) людей. Граждане, участвующие сегодня в подобных объединениях, лучше начинают понимать сложность решаемых проблем, повышают свою правовую грамотность, приобретают организаторский опыт. Участие граждан в работе ТСЖ создает хорошие условия для роста новых не формальных лидеров общественности. Самоорганизация населения в общественные объединения происходит там, где и когда люди, живущие рядом, осознают общие потребности, интересы и объединяются для их реализации. В связи с чем, базой для развития подобных общественных отношений могут стать и товарищества собственников жилья.

В результате деятельности товарищества, на его базе постепенно будет создана новая социальная общность - собственников жилья многоквартирных домов, которые через собственный опыт управления многоквартирным домом как хозяйственной единицы приобретут понимание механизма управления более масштабных объединений - муниципальных образований, области, государства.

Вместе с тем процесс создания ТСЖ в стране идет крайне медленно. Всего 10,28 $\%$ многоквартирных домов сегодня организованы в товарищества собственников жилья. Наиболее серьезные причины такой ситуации, связаны с нежеланием населения, брать на себя обременительную ответственность по управлению многоквартирным домом, отсутствие необходимой правовой и общей культуры, высокий уровень социальной дифференциации жителей одного дома, низкая информированность населения о возможностях и перспективах ТСЖ, отсутствия у органов местного самоуправления заинтересованности в развитии таких форм, несовершенство законодательства в области регулирования деятельности товариществ, низкий уровень правовой защищенности собственников в условиях ТСЖ.

Также процесс внедрения ТСЖ замедляется в связи с несовершенством сектора коммунальных услуг в стране, отчасти - с недостаточной способностью граждан к самоорганизации. Жильцы должны уметь самоорганизоваться, составить эффективно действующий коллектив.

С принятием Жилищного кодекса процесс создания ТСЖ ускорился, однако, жильцы почти трети домов до сих пор не избрали какую-либо форму управления общей собственностью. ТСЖ введены лишь в 1/7 жилого фонда страны. Препятствиями на пути создания товариществ являются недоверие в обществе к реформе ЖКХ, недостаточная информированность населения об этой реформе, опасения, что создание ТСЖ приведет к росту стоимости коммунальных услуг и более жесткому порядку взыскания платежей, неурегулированная ответственность за капитальный ремонт изношенного жилого фонда, споры вокруг закрепления в собственность ТСЖ земельных участков.

Подводя итог всему выше сказанному, необходимо отметить, что ТСЖ является довольно-таки эффективной и перспективной формой управления МКД, но в связи с тем, что данная модель управления недостаточно развита и понятна гражданам, большая часть МКД заключает договоры с управляющими компаниями. 
Для развития ТСЖ требуется совершенствование законодательной базы в этом сфере, создание социального партнерства, направленного на объединение усилий общественности и государственных структур в деле пропаганды и развития ТСЖ, а также разработки эффективной модели управления товариществом.

$$
* * *
$$

1. Гражданский кодекс Российской Федерации (часть первая): федеральный закон от $30.11 .1994 \mathrm{~N}$ 51-Ф3 // "Российская газета", N 238-239, 08.12.1994 (ред. от 29.12.2017).

2. Жилищный кодекс Российской Федерации: федеральный закон от 29.12.2004 N 188 -Ф3 // "Российская газета", N 1, 12.01.2005 (ред. от 31.12.2017).

3. О порядке осуществления деятельности по управлению многоквартирными домами: Постановление Правительства РФ от 15.05.2013 N 416 // Собрание законодательства РФ, 27.05.2013, N 21, ст. 2652(ред. от 25.12.2015).

4. Габрусь, Н.В. Управление многоквартирным домом / Н.В. Габрусь // Журнал руководителя и главного бухгалтера ЖКХ. 2006. N 6. С. 10 - 13.

5. Гордеев, Д.П. Изменение правового статуса товариществ собственников жилья как объединения собственников жилых и нежилых помещений в многоквартирном доме / Д.П. Гордеев // Имущественные отношения в Российской Федерации. 2016. N 11. С. 26 - 39.

6. Звягинцев, М. МСУ и ТСЖ: конфликт или сотрудничество / М. Звягинцев // Самоуправление. 2010. N 2. C. $14-15$.

7. Конева, О.В. Территориальная организация граждан. Проблемы и перспективы организации товариществ собственников жилья / О.В. Конева // Стратегия устойчивого развития регионов России. 2010. № 4. С. 3-7.

8. Свит, Ю.П. Актуальные проблемы управления многоквартирными домами / Ю.П. Свит // Гражданское право. 2017. N 4. С. $20-23$.

\section{Густов $\mathbf{P}$.}

Споры, связанные с установлением публичного сервитута

ФГБОУ ВО «Кубанский государственный аграрный университет имени И.Т.

Трубилина»

(Россия, Краснодар)

doi: $10.18411 / \mathrm{j}-06-2021-205$

\section{Аннотация}

В данной статье рассматривается определение понятия «публичный сервитут», также изучаются и исследуются споры, возникающие между государственными органами и собственниками земельных участков. Раскрыт порядок установления публичного сервитута. Приведены примеры из практики, которые наиболее подробно раскрывают нюансы при возникновении подобного рода споров в сфере установления публичного сервитута.

Ключевые слова: публичный сервитут, правообладатель, собственник, земельный участок, спор.

\section{Abstract}

This articleexamines the definition of the concept of "public servitude", alsostudies and investigatesdisputesarisingbetweenstatebodies and owners of landplots. The procedure for establishing a public easement is disclosed. Examples from practice are given, whichreveal in the mostdetail the nuances in the occurrence of suchdisputes in the field of establishing a public easement.

Keywords: public servitude, copyrightholder, owner, landplot, dispute.

Само понятие «сервитут»настоящим, действующим законодательством Российской Федерации понимается, как вещное право ограниченного пользования чужим земельным участком. Публичный сервитут, являетсякак таковой возможностью 